\title{
Dietary Intake, Intestinal Infection, and Safe Drinking Water Among Children with Anemia in Peru: A Cross-Sectional Analysis
}

Christopher M Westgard ( $\square$ cmwestgard@gmail.com)

University of North Carolina at Chapel Hill https://orcid.org/0000-0002-8914-4021

Luis A. Orrego-Ferreyros

Elementos

Liz Franco Calderón

Elementos

Alexandra M. Rogers

Elementos

\section{Research article}

Keywords: Anemia, nutrition, diet, infectious disease, sanitation, Peru

Posted Date: October 15th, 2020

DOl: https://doi.org/10.21203/rs.3.rs-40610/v2

License: (9) (1) This work is licensed under a Creative Commons Attribution 4.0 International License. Read Full License

Version of Record: A version of this preprint was published at BMC Nutrition on June 3rd, 2021. See the published version at https://doi.org/10.1186/s40795021-00417-3. 


\section{Abstract}

Anemia is a major public health concern that is present in $41.7 \%$ of children under 5 worldwide. The prevalence of anemia in Peru was $43.6 \%$ in 2017 , a decrease by only $6.8 \%$ in 8 years. Despite great efforts made by the government to reduce anemia by distributing free multi-micronutrient supplements and promote the consumption of iron rich foods, progress has been slow. The current study sought to better understand the dietary intake, incidence of intestinal infectious disease, and access to safe drinking water by children with anemia in Peru to help explain why the prevalence remains high. METHODS A crosssectional analysis was conducted using data from two national surveys that were combined by child ID. Descriptive statistics was analyzed to understand the experience of children with anemia in comparison to child without anemia. Logistic multivariate regression analyses were conducted to test the associations between anemia and dietary intake, intestinal infection, and access to safe drinking water. RESULTS The sample included 586 children between 6 and 35 months. The prevalence of anemia in this population was $53.2 \%$. The portion of children that consumed sufficient micronutrients to meet the recommendation for their age was $51.9 \%$. Of the children with anemia, $45.1 \%$ consumed sufficient micronutrients to meet their recommendation, vs. $54.9 \%$ of children without anemia $(p<0.001)$. The children with anemia were more likely to have an intestinal infection in the last year $(35 \%$ vs. $26 \%, p=0.057)$ and less likely to have access to safe drinking water $(23 \%$ vs. $14 \%, p=0.02)$ than those without anemia.. The logistic analysis revealed that having an intestinal infection increased the odds of having anemia (OR=1.59, $\mathrm{Cl} 95 \%$ [1.01-2.49]), and having access to safe drinking waters decreased the odds of having anemia (OR=0.56, [0.320.96]), while controlling for the consumption of sufficient iron. CONCLUSIONS Nearly half of the children with anemia in Peru already consume sufficient micronutrients to meet their daily requirement. However, they continue to have anemia, likely due to intestinal infection, such as diarrhea and parasites, and a lack of access to safe drinking water.

\section{Background}

Proper nutrition outcomes in children, especially during the first 1000 days, are critical for healthy growth and development. ${ }^{1-4}$ However, in $2016,41.7 \%$ of children under 5 worldwide suffered from anemia, most often caused by micronutrient deficiencies. ${ }^{5}$ The health, development, and economic consequences of anemia are significant, and children under 5 bear the largest burden of the disease globally. ${ }^{6}$ Anemia delays the physical and cognitive development of children, reduces their energy level, and weakens their immune system. ${ }^{7,8}$ Additionally, the long-term economic costs from the decreased productivity and impaired cognitive development associated with childhood anemia have been estimated at US\$3.64 per person, or $0.81 \%$ of a country's gross domestic product (GDP). ${ }^{6} \mathrm{~A}$ deeper understanding of anemia's etiology is essential to appropriately combat the disease and reduce its effects on children's health and development, as well as on their ability to grow into productive members of their communities.

Anemia is a multicausal problem of complex etiology. The most common contributors to anemia are nutritional deficiencies, intestinal infections from parasites and bacteria, malaria, and genetic hemoglobin disorders. ${ }^{6}$ Iron deficiency is the most common cause of anemia which accounts for almost half of all cases in children under 5 years of age worldwide. ${ }^{6}$ Iron is an essential nutrient for hemoglobin and the production of red blood cells. Iron deficiency occurs when iron intake does not meet the body's iron requirements, due to poor diet or impaired absorption, causing the number of hemoglobin in the blood to decrease below the threshold of healthy levels determined by age, sex, and other factors. ${ }^{7,9}$ The body's need for iron is especially high during infancy and childhood when the body experiences rapid growth.

The prevalence and risk of iron deficiency anemia globally has also been linked to various socioeconomic determinants of health, such as proper sanitation and hygiene, parents' educational status, family income, and family size. ${ }^{10-12}$ Research in Peru has shown that childhood anemia is associated with poor intake of iron-rich foods, high prevalence of infectious diseases, a lack of safe water and basic sanitation, low birth weight, and reduced breastfeeding. ${ }^{13}$

In Peru, $43.6 \%$ of children below 3 years old had anemia in 2017 , while $50.4 \%$ had anemia in $2009 .{ }^{14}$ A decrease of $6.8 \%$ in 8 years. Reducing childhood anemia has become a high priority of the Peruvian National Government. The Government has created a multisectoral plan that aims to reduce anemia in children under 3 by over $24 \% .{ }^{15}$ National programs have focused primarily on providing multi-micronutrient supplement powders and educational campaigns to increase children's intake of iron rich foods. ${ }^{16}$ However, due to the multicausal nature of the disease, a multisectoral approach that goes beyond micronutrient supplementation and educational campaigns is needed.

A greater understanding of the nutritional, health, and behavioral characteristics of children with anemia in Peru will illuminate their needs and opportunities to create significant reduction of the illness. The current study conducts an analysis by linking two public data bases to illuminate the current situation of children with anemia in Peru, to improve understanding of their needs. The authors hypothesize infectious diseases and parasites in children and poor access to safe drinking water are significant drivers of anemia, independent of nutrition consumption. Therefore, improving nutrient uptake alone in the population will not solve the problem.

\section{Methods}

To explore the hypothesis, a cross-sectional analysis of secondary data was conducted to understand the characteristics associated with anemia in children under 3 years. The study links two public data bases to conduct the analysis; 1 ) the Food and Nutrition Surveillance Survey for Stages of Life (FNSS) in 20152016 (In Spanish: Encuesta de Vigilancia Alimentaria y Nutricional por Etapas de Vida, VIANEV) ${ }^{17}$ and 2) Health Benefits Report from the Integrated Health Services Systems of Comprehensive Health Insurance (ISHS) from the Ministry of Health in 2015-2016 (In Spanish: Reporte de Prestaciones de Salud del Sistema Integrado de Aseguramiento en Salud del Seguro Integral de Salud del Ministerio de Salud, SIASIS). ${ }^{18}$

The FNSS was carried out nationwide in Peru by the National Center for Food and Nutrition, of the National Institute of Health (Centro Nacional de Alimentación y Nutrición). The survey aimed to examine nutritional outcomes and food consumption in children under 3 years. The survey utilized a random 
cluster sample survey design representative of the national population. The complete methodology is described in the survey's final report published on the National Institute of Health's website. ${ }^{17}$ The survey included a 24-hour dietary recall that occurred on two non-consecutive days. The dietary information was converted into the amount of nutrients consumed and compared to the requirements for healthy growth of each nutrient to indicate if the child is meeting their nutritional requirements for their age. ${ }^{17,19-21}$

The ISHS is a public data base that contains information reported by all public health establishments nationwide on the medical care provided to the population covered by the public health insurance system. ${ }^{18}$ The database is available by request from the Ministry of Health of Peru. The illnesses were categorized to analyze similar illnesses together as a group, according to the International Classification of Diseases: Preparation of Short Lists for Data Tabulation. ${ }^{22}$ The primary predictor of interest from the data base is a reported infectious or parasitic illness in a health center for the child in 2016 . The ordinal variable ( $0-6$ cases of infection reported) was converted into a binary variable for the analysis that indicates if the child has had 0 reported infectious or parasitic illnesses at the health center during the year (2016), or 1 or more reported cases.

The current study conducted several analyses to understand the characteristics of children with anemia compared to those who do not have anemia. First, a Chi-Square analysis was conducted to assess the association of anemia with the consumption of recommend levels of nutrients. Second, the FNSS and ISHS are linked to analyze the relationship between anemia, infectious or parasitic disease (IPD), and access to safe drinking water. Chi-square analyses are conducted to assess the association between children with anemia and incidence of IPD and safe drinking water. Two logistic multivariant regression

analyses were conducted: 1 . to assess the influence of IPD on anemia, holding micronutrient uptake constant, 2 . to assess the influence of safe drinking water on anemia, holding micronutrient uptake constant.

Any cases that had omitted variables were not included in the analysis. The analysis adjusted for sampling design and clustering. The analysis was conducted with STATA/SE $16.1 .^{23}$

\section{Results}

The FNSS included 687 participants, with 586 participants between 6 to 35 months that included an indicator for anemia. Therefore, the sample size for our study was 586 . The sample was $53 \%$ male with an average age of 20 months. The proportion living in Metropolitan Lima was $35 \%, 27 \%$ in Urban areas, and $37 \%$ in Rural areas. The demographics, rates of anemia, and nutrient uptake are included in Table 1. 
Table 1

Characteristics of study population

\begin{tabular}{|c|c|}
\hline Characteristics & $N(\%)$ \\
\hline \multicolumn{2}{|l|}{ Children with anemia ${ }^{1}$} \\
\hline No & $274(46.8)$ \\
\hline Yes & $312(53.2)$ \\
\hline \multicolumn{2}{|c|}{ Children that meet recommendation for iron ${ }^{1}$} \\
\hline No & $218(38.4)$ \\
\hline Yes & $350(61.6)$ \\
\hline $\begin{array}{l}\text { Children that meet recomme } \\
\text { for iron, zinc and vitamin } A^{1}\end{array}$ & \\
\hline No & $282(48.1)$ \\
\hline Yes & $304(51.9)$ \\
\hline \multicolumn{2}{|c|}{ for iron, zinc, vitamin A, protein and, energy ${ }^{1}$} \\
\hline No & $342(58.4)$ \\
\hline Yes & $244(41.6)$ \\
\hline \multicolumn{2}{|l|}{$\operatorname{Sex}^{1}$} \\
\hline Male & $299(52.6)$ \\
\hline Female & $269(47.4)$ \\
\hline Age (months) ${ }^{1}$ & $20 \pm 8.5^{\star}$ \\
\hline \multicolumn{2}{|l|}{ Area of residence ${ }^{1}$} \\
\hline Metropolitan Lima & $201(35.4)$ \\
\hline Urban área & $154(27.1)$ \\
\hline Rural área & $213(37.5)$ \\
\hline \multicolumn{2}{|l|}{ Access to safe drinking water ${ }^{2}$} \\
\hline Do not Access & $106(18.1)$ \\
\hline Access & $480(81.9)$ \\
\hline \multicolumn{2}{|c|}{ Children with a reported infectious or parasitic disease ${ }^{2}$} \\
\hline None & $267(68.8)$ \\
\hline At least 1 reported infection & $121(31.2)$ \\
\hline \multicolumn{2}{|l|}{ * Mean \pm standard deviation } \\
\hline \multicolumn{2}{|c|}{ † Some values may not add up to 586 due to missing data. } \\
\hline \multicolumn{2}{|l|}{${ }^{1}$ Reported from FNSS } \\
\hline${ }^{2}$ Reported from ISHS & \\
\hline
\end{tabular}

The population had a prevalence of childhood anemia of $53.2 \%$. The distribution of children affected by anemia showed great discrepancy among the areas of residence, with the highest number in rural areas (Rural area: $64.3 \%$, Urban area: $54.5 \%$, Metropolitan Lima: $40.3 \%$ ). Children who met their iron recommendations for age was $61.6 \%$. Of the children with anemia, $45.1 \%$ meet their iron recommendation $(p<0.001)$. The children who met their recommendations for iron, zinc, and vitamin A was $51.9 \%$. Of the children with anemia, $45.1 \%$ met their recommendations for iron, zinc, and vitamin $A$ ( $p<$ 0.001). The children who met their recommendations for iron, zinc, vitamin A, protein and energy was $41.6 \%$. Of those with anemia, $45.1 \%$ meet their recommendations for iron, zinc, vitamin A, protein, and energy $(p=0.001)$. The association between nutrition uptake and anima is displayed in Table 2 . 


\begin{tabular}{|c|c|c|c|}
\hline \multirow[t]{3}{*}{ Variables } & \multicolumn{2}{|c|}{ Children with anemia } & $\mathbf{p}$ \\
\hline & No $(n=274)$ & Yes $(n=312)$ & \\
\hline & $n(\%)$ & $n(\%)$ & \\
\hline
\end{tabular}

\begin{tabular}{|c|c|c|c|}
\hline Area of residence & & & $<0.001$ \\
\hline Metropolitan Lima & $120(59.7)$ & $81(40.3)$ & \\
\hline Urban & $70(45.5)$ & $84(54.5)$ & \\
\hline Rural & $76(35.7)$ & $137(64.3)$ & \\
\hline Children that meet recommendation for iron & & & $<0.001$ \\
\hline No & $74(33.9)$ & $144(60.1)$ & \\
\hline Yes & $192(54.9)$ & $158(45.1)$ & \\
\hline Children that meet recommendation for iron, zinc, and vitamin A & & & $<0.001$ \\
\hline No & $107(37.9)$ & $175(62.1)$ & \\
\hline Yes & $167(54.9)$ & $137(45.1)$ & \\
\hline Children that meet recommendation for iron, zinc, vitamin A, protein and energy & & & 0.001 \\
\hline No & $140(40.9)$ & $202(59.1)$ & \\
\hline Yes & $134(54.9)$ & $110(45.1)$ & \\
\hline Children with an infectious or parasitic disease reported & & & 0.057 \\
\hline None & $121(73.8)$ & $143(64.4)$ & \\
\hline At least 1 & $43(26.2)$ & $78(35.6)$ & \\
\hline Access to safe drinking water & & & 0.002 \\
\hline No & $39(14.1)$ & $73(23.4)$ & \\
\hline \multirow[t]{3}{*}{ Yes } & $235(85.9)$ & $239(76.6)$ & \\
\hline & \multicolumn{2}{|c|}{ Children with safe drinking water } & \\
\hline & No $(n=75)$ & Yes $(n=293)$ & \\
\hline Children with an infectious or parasitic disease reported & & & 0.002 \\
\hline None & $47(62.7)$ & $245(84.6)$ & \\
\hline At least 1 & $28(37.3)$ & $48(15.4)$ & \\
\hline
\end{tabular}

The second-round of analysis included data linked from FNSS and the ISHS and had 388 participants. The prevalence of children who were reported to have an infectious or parasitic disease (IPD) in the last year was $31.2 \%$. Of those with anemia, $35 \%$ had an IPD, while those without anemia, $26 \%$ reported having an IPD, a difference of $35 \%(p=0.057)$. Regarding household sanitation, $18.1 \%$ of the children did not have access to safe drinking water. Of those with anemia, $23 \%$ did not have access to safe drinking water, while of those without anemia, $14 \%$ did not have access to safe drinking water $(p=0.020)$. Among the group of children who do not have access to safe drinking water, $37 \%$ had an IPD reported, of those that have safe drinking water, $15 \%$ had an IPD reported $(p=$ 0.002). The data on IPD, access to safe drinking water, and their relationship with children with anemia are included in Table 2 . An additional analysis was conducted to assess methods of water treatment: $85.8 \%$ (332) of the participants who have access to safe drinking water report boiling their water to treat it, $3.88 \%$ (15) report treating the water with chlorine, and $0.78 \%$ (3) report treating another way.

The logistic multivariant regression analysis displayed that having a IPD increases the odds of having anemia $(O R=1.6, p=0.043)$, independent of satisfying micronutrient uptake requirements (iron, zinc, and vitamin A). Additionally, having access to clean drinking water decreases the odds of anemia $(\mathrm{OR}=0.58, \mathrm{p}=$ 0.044), independent of satisfying micronutrient requirements. The results of the logistic regressions are in Table 3. 
Table 3

Logistic Regression Analysis to predict effect on anemia

\begin{tabular}{|llll|}
\hline $\mathbf{N}=\mathbf{3 9 8}$ & OR & P-value & 95\% Confidence Interval \\
\hline IPD & 1.6 & $0.043^{*}$ & $1.02-2.53$ \\
\hline Iron Requirements & 0.54 & $0.019 *$ & $0.32-0.90$ \\
\hline Zinc Requirements & 0.94 & 0.827 & $0.54-1.62$ \\
\hline Vitamin A Requirements & 0.92 & 0.78 & $0.52-1.62$ \\
\hline Intercept & 1.86 & 0.014 & $1.14-3.05$ \\
\hline Safe Drinking Water & 0.58 & 0.044 & $0.34-0.99$ \\
\hline Iron Requirements & 0.59 & 0.038 & $0.36-0.97$ \\
\hline Zinc Requirements & 0.86 & 0.591 & $0.51-1.48$ \\
\hline Vitamin A Requirements & 0.98 & 0.940 & $0.56-1.70$ \\
\hline Intercept & 3.04 & 0.000 & $1.63-5.65$ \\
\hline
\end{tabular}

\section{Discussion}

The results display that $41.6 \%$ of children with anemia in Peru already consume the recommended amount of micro- and macro-nutrients and $61.6 \%$ consume the recommended amount of iron. The portion of children in this study that consume the recommended amount of nutrients were similar to a study in Peru in 2014 , which showed that $51 \%$ of children under 3 met their iron uptake requirements and $60 \%$ met their energy intake requirements. ${ }^{24}$ The similarity in findings gives us greater confidence in the results of the current study. The study in 2014 , however, did not assess the nutrient and disease profile of the children with anemia. It could have been assumed that the children with anemia were those that did not consume the recommended levels of micronutrients.

The causes of anemia include poor nutrient intake, infectious diseases, parasites, inflammation, and hemoglobinopathies. ${ }^{6}$ The risk of anemia is greater when a population has frequent infection and does not have safe drinking water or proper sanitation, and does not have access to education and economic opportunities. ${ }^{19}$ We see in the current study that nearly half of the children with anemia consume enough nutrients, but it is not being appropriately absorbed and converted into hemoglobin. We must look beyond diet to fully understand the drivers of anemia. By integrating medical care data with the nutrition survey we were able to investigate other drivers of anemia, independent of nutrition uptake. We analyzed the association between anemia and IPD. IPD, including diarrhea and helminth infections, have been linked to the development of anemia. ${ }^{26-30}$ The current study found that the children with anemia have $37 \%$ more cases of IPD per year than children without anemia. The logistic regression displayed that the presence of an IPD increases the odds of having anemia (OR = $1.6, p=0.043$ ), while holding micronutrient uptake constant. The results help explain why so many children still have anemia, following years of national campaigns to provide micronutrient supplements and education campaigns to increase iron uptake. Strategies that do not address the presence of disease in children will continue to produce poor impact on the reduction of anemia. ${ }^{24-26}$ We must look at ways to prevent diarrhea, infectious diseases, and helminth infections in order to reduce children's risk of anemia.

Access to safe drinking water is associated with a lower risk of diarrhea and helminth infections; and diarrhea and helminth infections can cause anemia. ${ }^{26,27,33}$ The current study found that children with access to safe drinking water are less likely to have anemia $(O R=0.58, p=0.044)$, while holding micronutrient uptake constant. However, in a country that is prioritizing the reduction of anemia, $19.6 \%$ still do not have access to safe drinking water. This study highlights the importance of improving access to safe drinking water and promoting proper sanitation and hygiene, as a way to reduce children's risk for anemia.

A limitation of the data used is that the indicator for IPD includes only the cases that are reported in the health posts, and thus misses many incidences of diseases that are not reported due to poor access to health services and poor reporting. The number of IPDs children experience is expected to be much higher. Nutritional surveys also have their limitations that must be considered, included over or under reporting the amount and type of food consumed during the previous day. The bias was reduced by surveying the home on two separate, non-consecutive days.

\section{Conclusion}

The present study has provided us with the opportunity to explore more deeply the characteristics of children with anemia in Peru to understand the factors that maintain the high prevalence of anemia in children below 3 years of age. The analysis hopes to show that the causes of anemia are diverse, and thus demand a diverse national strategy. The problem cannot be solved while children continue to live with poor sanitation and high incidence of disease. The promotion of iron consumption and micronutrient supplements alone will not be enough.

Our study has found that access to safe drinking water and incidence of IPD are significantly associated with anemia. To reduce the incidence of IPD and anemia, national policies to improve access to safe drinking water must be implemented. It is essential that any approach to combat anemia in Peru focuses not only on the dietary causes of anemia, but also addresses the social determinants that affect children's health.

\section{Abbreviations}


FNSS: Food and Nutrition Surveillance Survey for Stages of Life

IPD: Infectious or Parasitic disease

ISHS: Health Benefits Report from the Integrated Health Services Systems of Comprehensive Health Insurance

SIASIS: Reporte de Prestaciones de Salud del Sistema Integrado de Aseguramiento en Salud del Seguro Integral de Salud del Ministerio de Salud VIANEV: Encuesta de Vigilancia Alimentaria y Nutricional por Etapas de Vida

\section{Declarations}

\section{Ethics Approval and Consent to Participate}

The current study was approved by the Institutional Review Board of the Office of Human Research Ethics of the University of North Carolina - Chapel Hill (Reference ID 281768).

\section{Consent for Publication}

Not applicable

\section{Availability of Data and Materials}

The dataset supporting the conclusions of this article is available in the figshare repository, $10.6084 / \mathrm{m} 9$. figshare.12574001.

\section{Competing Interests}

The authors declare that they have no competing interests

\section{Funding}

The authors were partially supported to conduct the research by Elementos. The authors also volunteered their time to conduct the study.

\section{Authors' Contributions}

CMW, LAOF, and LFC designed the study, analyzed the data, and wrote the manuscript. AMR wrote the manuscript and revised the analysis.

\section{Acknowledgements}

Not applicable

\section{References}

1. Black MM, Walker SP, Fernald LCH, et al. Early childhood development coming of age: science through the life course. Lancet. 2017;389(10064):77-90. doi:10.1016/S0140-6736(16)31389-7

2. Grantham-McGregor S, Cheung YB, Cueto S, et al. Developmental potential in the first 5 years for children in developing countries. Lancet. 2007;369(9555). doi:10.1016/S0140-6736(07)60032-4

3. Engle PL, Fernald LC, Alderman H, et al. Strategies for reducing inequalities and improving developmental outcomes for young children in low-income and middle-income countries. The Lancet. 2011;378(9799):1339-1353. doi:10.1016/S0140-6736(11)60889-1

4. Walker SP, Wachs TD, Grantham-McGregor S, et al. Inequality in early childhood: risk and protective factors for early child development. Lancet. 2011;378(9799):1325-1338. doi:10.1016/S0140-6736(11)60555-2

5. Prevalence of Anemia among Children (\% of Children under 5) | Data. The World Bank; 2016. Accessed September 27, 2019. https://data.worldbank.org/indicator/SH.ANM.CHLD.ZS

6. Nutritional Anaemias: Tools for Effective Prevention and Control. World Health Organization; 2017.

7. Desforges JF, Oski FA. Iron deficiency in infancy and childhood. The New England Journal of Medicine; Boston. 1993;329(3):190-193.

8. Carter RC, Jacobson JL, Burden MJ, et al. Iron deficiency anemia and cognitive function in infancy. Pediatrics. 2010;126(2):e427-434. doi:10.1542/peds.2009-2097

9. Camaschella C. Iron-Deficiency Anemia. New England Journal of Medicine. 2015;372(19):1832-1843. doi:10.1056/NEJMra1401038

10. Osório MM. Determinant factors of anemia in children. J Pediatr (Rio J). 2002;78(4):269-278. doi:10.2223/jped.860 
11. Subramaniam G, Girish M. Iron deficiency anemia in children. Indian J Pediatr. 2015;82(6):558-564. doi:10.1007/s12098-014-1643-9

12. Solar O, Irwin A. A Conceptual Framework for Action on the Social Determinants of Health. Social Determinants of Health Discussion Paper 2. World Health Organization; 2010.

13. Sobrino M, Gutierrez Villafuerte C, Ledo Alves Da Cunha AJ, Alarcon J. Desnutrición infantil en menores de cinco años en Perú: Tendencias y Factores Determinantes. Rev Panam Salud Publica 35(2):104-112. Published online 2014.

14. Encuesta Demográfica y de Salud Familiar 2018 - Nacional y Regional. Instituto Nacional de Estadística e Informática, Peru; 2018. Accessed April 3, 2020. https://www.inei.gob.pe/media/MenuRecursivo/publicaciones_digitales/Est/Lib1656/index1.html

15. Plan Multisectorial de Lucha Contra La Anemia. Ministerio de Desarrollo e Inclusion Social, Peru; 2018.

16. Anemia En La Población Infantil Del Perú: Aspectos Clave Para Su Afronte. Instituto Nacional de Salud, Peru; 2017. http://www.ins.gob.pe/repositorioaps/0/4/jer/evidencias/ANEMIA FINAL_v.03mayo2015.pdf

17. Informe Final. Encuesta: Vigilancia Alimentaria y Nutricional Por Etapas de Vida - VIANEV - Niños Menores de 36 Meses - 2015. Ministerio de Salud, Instituto National de Salud, Centro Nacional de Alimentacion y Nutricion; 2016.

https://web.ins.gob.pe/sites/default/files/Archivos/cenan/van/vigilacia_poblacion/Informe_VIANEV_Ninos_2015.pdf

18. Seguro Integral de Salud. Base de Datos de Prestaciones de Salud. 2015-2016. Ministerio de Salud de Peru; 2017.

19. Human Energy Requirements. Report of Joint FAO/WHO/UNU Expert Consultation.; 2001. http://www.fao.org/3/a-y5686e.pdf

20. Protein and Amino Acid Requirements in Human Nutrition. Report of a Join FAO/WHO/UNU Expert Consultation. World Health Organization; 2007. http://www.who.int/nutrition/publications/nutrientrequirements/WHO_TRS_935/en/

21. Fats and Fatty Acids in Human Nutrition -Report of an Expert Consultation. Food and Agriculture Organization of the United Nations.; 2010. http://www.fao.org/3/a-i1953e.pdf

22. Becker R. International Classification of Diseases: Preparation of Short Lists for Data Tabulation. Epidemiological Bulletin / PAHO. 2002;23(4). Accessed April 4, 2020. https://www.paho.org/english/dd/ais/be_v23n4-short_list.htm

23. Stata: Software for Statistics and Data Science. Accessed October 2, 2018. https://www.stata.com/

24. Tarqui Mamani CB, Rosales Pimentel S. Informe Technico: Vigilancia de Indicadores Nutricionales. Consumo de Alimentos En Niños Peruanos de 6 a 35 Meses 2013-2014. Ministerio de Salud, Instituto Nacional de Salud, Centro Nacional de Alimentacion y Nutricion; 2015.

https://web.ins.gob.pe/sites/default/files/Archivos/cenan/van/vigilacia_poblacion/CONSUMO\%20DE\%20ALIMENTOS\%20EN\%20NINOS\%20PERUANOS\% 2014.pdf

25. Zavaleta N. Anemia infantil: Retos y Oportunidades al 2021. Rev Peru Med Exp Salud Publica. 2017;34(4)588-89.

26. Larsen DA, Grisham T, Slawsky E, Narine L. An individual-level meta-analysis assessing the impact of community-level sanitation access on child stunting, anemia, and diarrhea: Evidence from DHS and MICS surveys. PLOS Neglected Tropical Diseases. 2017;11(6):e0005591. doi:10.1371/journal.pntd.0005591

27. Wolf J, Prüss-Ustün A, Cumming O, et al. Systematic review: Assessing the impact of drinking water and sanitation on diarrhoeal disease in low- and middle-income settings: systematic review and meta-regression. Tropical Medicine \& International Health. 2014;19(8):928-942. doi:10.1111/tmi.12331

28. Bechir M, Schelling E, Hamit MA, Tanner M, Zinsstag J. Parasitic infections, anemia and malnutrition among rural settled and mobile pastoralist mothers and their children in Chad. Ecohealth. 2012;9(2):122-131. doi:10.1007/s10393-011-0727-5

29. Jonker FAM, Calis JCJ, Phiri K, et al. Real-time PCR demonstrates Ancylostoma duodenale is a key factor in the etiology of severe anemia and iron deficiency in Malawian pre-school children. PLoS Negl Trop Dis. 2012;6(3):e1555. doi:10.1371/journal.pntd.0001555

30. Evaluación Basal de Anemia Por Deficiencia de Hierro y Folatos En Mujeres En Edad Fértil y En Niños y Niñas de 24 a 59 Meses En Lima Metropolitana. Instituto Nacional de Salud; 2006. Accessed August 21, 2019. http://catalog.ihsn.org/index.php/citations/82226

31. Balarajan Y, Ramakrishnan U, Ozaltin E, Shankar AH, Subramanian SV. Anaemia in low-income and middle-income countries. Lancet. 2011;378(9809):2123-2135. doi:10.1016/S0140-6736(10)62304-5

32. Ngui R, Lim YAL, Chong Kin L, Sek Chuen C, Jaffar S. Association between Anaemia, Iron Deficiency Anaemia, Neglected Parasitic Infections and Socioeconomic Factors in Rural Children of West Malaysia. PLoS Negl Trop Dis. 2012;6(3). doi:10.1371/journal.pntd.0001550

33. Humphrey JH, Mbuya MNN, Ntozini R, et al. Independent and combined effects of improved water, sanitation, and hygiene, and improved complementary feeding, on child stunting and anaemia in rural Zimbabwe: a cluster-randomised trial. Lancet Glob Health. 2019;7(1):e132-e147. doi:10.1016/S2214109X(18)30374-7 